\title{
Assessment of Genetic Diversity in Promising Bread Wheat (Triticum aestivum L.) Genotypes
}

\author{
Rajshree* and Satish Kumar Singh \\ Department of Plant Breeding and Genetics, Rajendra Agricultural University, Pusa, \\ Samastipur, Bihar - 848 125, India \\ *Corresponding author
}

\section{A B S T R A C T}

\section{Keywords}

Wheat (Triticum aestivum L.), Genetic divesity

\section{Article Info}

Accepted:

07 February 2018

Available Online:

10 March 2018

An experiment with thirty three genotypes of bread wheat carried out to study the nature and magnitude of divergence using Mahalanobis $\mathrm{D}^{2}$ statistics, in randomized block design with three replications. The data for thirteen important quantitative traits were recorded from the genotypes raised. The variability study indicated high to moderate phenotypic and genotypic coefficient of variation accompanied by high heritability and genetic advance as per cent of mean for traits, plant height, number of tillers per plant, flag leaf area, chlorophyll content, canopy temperature, spike length, grains per spike, grain yield per plot and harvest index indicating their importance in selection for yield improvement. The thirty three genotypes of bread wheat were grouped into six clusters using Tocher's method. The genotypes in cluster III and cluster VI, exhibited high degree of genetic diversity. Cluster I was suitable for spike length, flag leaf area, grains per spike, thousand grain weight, and grain yield per plot. Days to fifty per cent flowering and harvest index contributed maximum towards genetic divergence.

\section{Introduction}

Wheat (Triticum aestivum L.) is considered as king of cereals and it provides foods to $36 \%$ of the global population, contributing $20 \%$ of the food calories. It is an important staple food of many countries in the world and occupies a unique position as used for the preparation of a wide range of food stuffs. Over the past century selection of desirable parents for hybridization programme has been found as an effective operating implement in developing high yielding crop varieties upon which, the modern agriculture can rely. Efficient and economic crop improvement scheme refers to the collection of superior alleles into a single population. Genetic variability in a population can be partitioned into heritable and nonheritable variation with the aid of genetic parameters such as variance, genotypic coefficient of variation, heritability and genetic advance, which serve as a basis for selection of some outstanding genotypes from existing ones (Tsegaye et al., 2012). Choice of parents is not only based on desirable agronomic traits, components of yield and extent of variability but also on heritability of yield contributing traits. The environment, in which selection is made, is also important because heritability and genetic advance vary 
with change in environment (Korkut et al., 2001). The study of genetic variability reveals about the presence of variation in their genetic constitution and it is outmost important as it provide the basis of effective selection. Grain yield is a complex trait and highly influenced by many genetic factors and environmental fluctuations. In plant breeding programme, direct selection for yield as such could be misleading. A successful selection depends upon the information on the genetic variability and association of morpho-agronomic traits with grain yield. In views of these facts, thirty three wheat genotypes were evaluated in this study to determine the magnitude of variability among the germplasm and grouping pattern of genotypes in different cluster. To identify genetically diverse and agronomically desirable genotypes for exploitation in a breeding programme aimed at improving grain yield potential of wheat.

\section{Materials and Methods}

The experiment was conducted in a randomized block design with three replications. The experimental materials were sown during Rabi, 2015 keeping plot size 3.0 $\mathrm{m} \times 2.5 \mathrm{~m}$. In each replication each genotype was grown in a plot of 5 rows of 3 meter length each with a spacing of $22.5 \mathrm{~cm}$ between rows. In order to compare the genotype unbiaselly, uniform plant population was kept in each row. Five random plants per genotype per replication were tagged to record observations on yield and yield attributing traits viz., days to fifty per cent flowering, days to maturity, plant height, number of tillers per plant, spike length, flag leaf area, chlorophyll content, canopy temperature, relative water content, number of grains per spike, grain yield per plot, harvest index, 1000-grain weight. Flag leaf length and width of five randomly selected plants were taken by measuring scale and flag leaf area was calculated by following formula:
Flag leaf area $\left(\mathrm{cm}^{2}\right)=$ flag leaf length $(\mathrm{cm}) \mathrm{x}$ flag leaf width (cm) (Mokhtarpour et al., 2010).

Harvest index was calculated as per the formula (Huhn 2008).

H.I. $=\frac{\text { Economic } \quad \text { yield }}{\text { Biological yield }} \times 100$

Where,

Economic yield $=$ Grain yield $(\mathrm{g})$

Biological yield $=$ Total plant yield $(\mathrm{g})$

The data were analyzed using WINDOSTAT version 9.1 software for computation of analysis of variance, genotypic coefficient of variation (GCV), phenotypic coefficient of variation (PCV), heritability in broad sense $\left(\mathrm{h}^{2} \mathrm{~b}\right)$ and clustering by Tocher's method.

\section{Results and Discussion}

In the present investigation, Thirty three diverse genotypes of bread wheat were studied to assess their yield and yield related attributing characters. The analysis of variance clearly indicated that there was highly significant variation among the genotypes for all the traits studied. This in turn indicated that there was sufficient variability in the material studied, which could be utilized in further breeding programme. Similarly, many earlier workers, Bhushan et al., (2013), Degewione et al., (2013), Fellahi et al., (2013), Kumar et al., (2014) and Yadav et al., (2014) reported high variability for different traits in bread wheat which provides ample scope for selecting superior and desire genotypes by the plant breeder for further improvement.

The phenotypic variances (Table 1) for all the traits under studied were higher than the genotypic variances (Yadav et al., 2006). This 
may be due to the non-genetic factor which played an important role in the manifestation of these characters. Wide ranges of variance (phenotypic and genotypic) were observed in the experimental material for all the characters under investigation. The maximum phenotypic and genotypic variance exhibited by the traits, grain yield per plot, grains per spike, harvest index, chlorophyll content, plant height, relative water content, days to fifty per cent flowering and days to maturity. These findings were in accordance of Singh et al., (2003), Sen et al., (2007), Majumder et al., (2008) and Kumar et al., (2009). The genotypic and phenotypic coefficients of variation for grains per spike and harvest index were found high indicating the importance of this trait in evaluation and selection of the genotypes. These results are in agreement with Raj Bahadur and Lodhi (1995), Singh et al., (2003), Yadav et al., (2006), Sen et al., (2007), Ali et al., (2008) and Kumar et al., (2014).

High heritability in broad sense were recorded for all the characters namely tillers per plant, flag leaf area, days to fifty per cent flowering, chlorophyll content, canopy temperature, relative water content, spike length, grains per spike, days to maturity, 1000-grain weight and grain yield per plot. High heritability value for these traits indicated that the variation observed was mainly under genetic control and was less influence by environment. So, these traits may be used as selection criteria for yield improvement in confirmation with the result of earlier workers viz., Islam et al., (2012), Kumar et al., (2014) and Fellahi et al., (2013). In the present investigation, the characters, namely tillers per plant, flag leaf area, chlorophyll content, canopy temperature, spike length, grains per spike, grain yield per plot and harvest index have high heritability and genetic advance as per cent of mean. The high heritability associated with high genetic advance indicated, the variation was mostly due to additive gene effects. Hence, direct selection can be done through these characters for future improvement of genotypes for higher grain yield. Similar results were also reported by earlier workers (Islam et al., 2012; Singh et al., 2014 and Yadav et al., 2014).

Thirty three genotypes (including check) were grouped into six clusters on the basis of $\mathrm{D}^{2}$ statistics (Table 2). Cluster I and IV had maximum number of genotypes (9) viz., $21^{\text {st }}$ SAWYT307, $21^{\text {st }}$ SAWYT332, $34^{\text {th }}$ ESWYT146, 46 ${ }^{\text {th }}$ IBWSN1095, AKAW4900, $8^{\text {th }} \quad$ EBWYT507, LBPY-2014-7, $21^{\text {st }}$ SAWYT316 and LBPY 2013-1 in cluster I and HD2643, PBW343, 3043, 46th IBWSN1113, HD2733, HD2967, 34th ESWYT124,, PBW373, 46th IBWSN1107 in cluster IV respectively. Cluster II and V had five genotypes each viz., 4051, 7004, 3054, 4043, HUW234 in cluster II and 6041, HD2932, LBPY-2014-2, RAJ4120 and DBW14 in cluster V respectively. Cluster VI had four genotypes viz., 5011, $34^{\text {th }}$ ESWYT121, DBW15, DBW39. Cluster III was solitary, comprising single genotype viz., GW2013-471. The clustering pattern showed that there was no formal relationship between geographical diversity and genetic diversity. Similar studied based on $\mathrm{D}^{2}$ statistic was also performed by Shoran and Tondon (1995), Ribadia et al., (2007), Roy et al., (2009) and Ferdous et al., (2011). Different clusters comprises unique feature for different characters under investigation. Cluster III had the maximum mean value for thousand grain weight, grain weight per plot, chlorophyll content, relative water content and harvest index. Cluster III had genotype with low mean value for canopy temperature. Cluster I had the genotype with the highest mean value for tillers per plant, spike length, flag leaf area and grains per spike. Cluster V may be selected as a donor for dwarfness as well as for early maturity (Table 3 ). 
Table.1 Estimates of variability parameter of yield and yield attributing traits

\begin{tabular}{|c|c|c|c|c|c|c|c|}
\hline SI. No & Characters & $\sigma_{\mathrm{g}}^{2}$ & $\sigma_{p}^{2}$ & GCV & PCV & $h^{2}$ (Broad sense) $\%$ & GA as \% of Mean \\
\hline 1 & Plant height $(\mathrm{cm})$ & 37.91 & 96.20 & 7.04 & 11.21 & 39.41 & 9.10 \\
\hline 2 & Days to 50 per cent flowering & 26.48 & 27.12 & 7.08 & 7.16 & 97.65 & 14.41 \\
\hline 3 & Flag Leaf Area $\left(\mathrm{cm}^{2}\right)$ & 11.12 & 14.81 & 16.62 & 19.18 & 75.11 & 29.67 \\
\hline 4 & Numbers of Tillers per Plant & 1.24 & 1.87 & 19.57 & 24.06 & 66.17 & 32.79 \\
\hline 5 & Chlorophyll content & 42.17 & 46.31 & 16.13 & 16.90 & 91.07 & 31.72 \\
\hline 6 & Canopy temperature & 10.48 & 14.88 & 15.68 & 18.69 & 70.43 & 27.12 \\
\hline 7 & Relative water content & 35.17 & 55.63 & 6.59 & 8.29 & 63.23 & 10.79 \\
\hline 8 & Spike length & 1.44 & 1.61 & 11.14 & 11.80 & 89.09 & 21.66 \\
\hline 9 & Number of grains per spike & 115.14 & 126.54 & 22.72 & 23.82 & 90.99 & 44.65 \\
\hline 10 & Days to maturity & 24.70 & 31.52 & 4.35 & 4.91 & 78.36 & 7.94 \\
\hline 11 & 1000 grain weight & 12.39 & 14.73 & 8.68 & 9.46 & 84.16 & 16.41 \\
\hline 12 & Grain yield per plot & 3589.82 & 4304.15 & 14.96 & 16.39 & 83.40 & 28.16 \\
\hline 13 & Harvest Index (\%) & 103.85 & 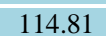 & 22.14 & 23.27 & 90.46 & 43.36 \\
\hline
\end{tabular}

Where, $\sigma_{g}^{2}$ Genotypic variance, $\sigma_{p}^{2}$ Phenotypic variance, GCV= Genotypic coefficient of variation, PCV=Phenotypic coefficient of variation $h^{2}=$ heritability, $\mathrm{GA}=$ Genetic Advance

Table.2 Clustering pattern of 33 genotypes of bread wheat on the basis of $\mathrm{D}^{2}$ statistic

\begin{tabular}{|c|c|c|}
\hline Cluster No. & $\begin{array}{c}\text { No. of Genotypes within } \\
\text { cluster }\end{array}$ & Genotypes in cluster \\
\hline $\mathbf{I}$ & 9 & $21^{\text {st }}$ SAWYT307, $21^{\text {st }}$ SAWYT332, 34 $4^{\text {th }}$ ESWYT146, 46 1 thWSN1095, AKAW4900, $8^{\text {th }}$ EBWYT507, LBPY-2014-7, 21 $1^{\text {st }}$ SAWYT316, LBPY 2013-1 \\
\hline II & 5 & 4051, 7004, 3054, 4043, HUW234 \\
\hline III & 1 & GW2013-471 \\
\hline IV & 9 & HD2643, PBW343, 3043, 46th IBWSN1113, HD2733, HD2967, 34th ESWYT124,, PBW373, 46th IBWSN1107 \\
\hline $\mathbf{V}$ & 5 & 6041, HD2932, LBPY-2014-2, RAJ4120,DBW14 \\
\hline VI & 4 & $5011,34^{\text {th }}$ ESWYT121, DBW15, DBW39 \\
\hline
\end{tabular}

Table.3 Cluster mean for thirteen characters in bread wheat

\begin{tabular}{|c|c|c|c|c|c|c|c|c|c|c|c|c|c|}
\hline Cluster No. & PH & TPP & SL & FLA & DFF & G/S & TGW & GW/P & $\mathrm{CC}$ & RWC & $\mathrm{CT}$ & DTM & HI \\
\hline I & 95.45 & 6.01 & 12.23 & 21.42 & 74.41 & 59.11 & 42.85 & 435.56 & 44.04 & 92.07 & 19.48 & 113.85 & 51.79 \\
\hline II & 85.28 & 5.90 & 10.31 & 17.92 & 65.27 & 48.69 & 37.33 & 349.33 & 32.80 & 81.87 & 25.47 & 110.40 & 35.94 \\
\hline III & 86.73 & 5.90 & 12.20 & 20.80 & 69.00 & 51.50 & 44.00 & 515.00 & 47.33 & 96.67 & 16.33 & 115.00 & 62.48 \\
\hline IV & 84.27 & 5.86 & 10.32 & 21.17 & 77.30 & 41.37 & 40.00 & 420.19 & 43.81 & 94.11 & 18.85 & 116.96 & 49.06 \\
\hline $\bar{V}$ & 81.94 & 4.87 & 9.73 & 17.55 & 67.07 & 40.89 & 40.73 & 403.33 & 42.33 & 93.67 & 18.33 & 108.53 & 48.09 \\
\hline VI & 86.75 & 5.22 & 9.91 & 20.17 & 75.75 & 38.62 & 39.50 & 307.25 & 28.67 & 79.67 & 25.17 & 120.17 & 32.26 \\
\hline
\end{tabular}

Abbreviations- Plant Height (PH), Tillers per plant (TPP), Spike length (SL),Flag Leaf Area (FLA), Days to 50 per cent flowering (DFF), Grains per spike (GPS),1000-Grain weight (TGW), Grain yield per plot (GWP), Chlorophyll content (CC), Relative water content (RWC), Canopy temperature (CT), Days to Maturity (DTM), Harvest Index (HI) 
Table.4 Mean intra and inter cluster distance $\left(\mathrm{D}^{2}\right)$ among six cluster in bread wheat

\begin{tabular}{|c|c|c|c|c|c|c|} 
& Cluster I & $\begin{array}{c}\text { Cluster } \\
\text { II }\end{array}$ & $\begin{array}{c}\text { Cluster } \\
\text { III }\end{array}$ & $\begin{array}{c}\text { Cluster } \\
\text { IV }\end{array}$ & $\begin{array}{c}\text { Cluster } \\
\text { V }\end{array}$ & Cluster VI \\
\hline Cluster I & $\mathbf{3 4 . 1 2}$ & 138.36 & 59.05 & 69.86 & 115.56 & 124.98 \\
\hline Cluster II & & $\mathbf{2 2 . 6 7}$ & 145.25 & 187.99 & 93.52 & 118.96 \\
\hline Cluster III & & & $\mathbf{0 . 0 0}$ & 89.73 & 51.46 & 208.33 \\
\hline Cluster IV & & & & $\mathbf{4 9 . 3 6}$ & 125.17 & 119.81 \\
\hline Cluster V & & & & & $\mathbf{3 2 . 2 7}$ & 196.07 \\
\hline Cluster VI & & & & & & $\mathbf{5 0 . 0 5}$ \\
\hline
\end{tabular}

Table.5 Diverse bread wheat genotypes based on cluster mean and superior per se performance for the traits under investigation

\begin{tabular}{|c|c|c|c|c|}
\hline $\begin{array}{l}\text { Sl. } \\
\text { No. }\end{array}$ & Characters & Cluster & Suitable Parents in Cluster & $\begin{array}{c}\text { Per se } \\
\text { Performance }\end{array}$ \\
\hline 1 & Plant Height $(\mathrm{cm})$ & V & $\begin{array}{l}\text { RAJ4120 } \\
\text { DBW14 }\end{array}$ & $\begin{array}{l}70.40 \\
75.10\end{array}$ \\
\hline 2 & Tillers per plant & I & LBPY2014-7 & 7.13 \\
\hline 3 & Spike length $(\mathrm{cm})$ & I & $\begin{array}{l}8^{\text {th }} \text { EBWYT507* } \\
34^{\text {th }} \text { ESWYT146* } \\
\text { AKAW4900* } \\
21^{\text {st }} \text { SAWYT332* } \\
\text { LBPY2013-1* } \\
46^{\text {th }} \text { IBWSN1095* } \\
21^{\text {st }} \text { SAWYT307* } \\
\text { LBPY-2014-7* } \\
21^{\text {st }} \text { SAWYT316* }\end{array}$ & $\begin{array}{l}13.20 \\
12.73 \\
12.53 \\
12.47 \\
12.43 \\
12.10 \\
11.73 \\
11.46 \\
11.43\end{array}$ \\
\hline 4 & Flag leaf area $\left(\mathrm{cm}^{2}\right)$ & I & AKAW4900 & 25.45 \\
\hline 5 & $\begin{array}{l}\text { Days to fifty per cent } \\
\text { flowering }\end{array}$ & II & $\begin{array}{l}7004^{*} \\
4043^{*} \\
4051^{*} \\
3054^{*} \\
\text { HUW234* }\end{array}$ & $\begin{array}{l}63.00 \\
64.00 \\
64.66 \\
66.33 \\
68.33\end{array}$ \\
\hline 6 & Grains per spike & I & $\begin{array}{l}21^{\text {st }} \text { SAWYT332* } \\
46^{\text {th }} \text { IBWSN1095* } \\
21^{\text {st }} \text { SAWYT307* } \\
21^{\text {st }} \text { SAWYT316* LBPY-2014- } \\
7^{*} \\
\text { AKAW4900* LBPY2013-1* } \\
34^{\text {th }} \text { ESWYT146* } \\
8^{\text {th }} \text { EBWYT507* }\end{array}$ & $\begin{array}{l}69.13 \\
65.66 \\
64.20 \\
58.96 \\
57.76 \\
55.93 \\
53.70 \\
53.66 \\
52.96\end{array}$ \\
\hline 7 & Thousand grain weight & I & LBPY2013-1 & 46.66 \\
\hline 8 & Grain yield per plot $(\mathrm{g})$ & I & LBPY-2014-7* & 488.33 \\
\hline 9 & Chlorophyll content & III & GW2013-471* & 47.33 \\
\hline 10 & Relative water content & III & GW2013-471 & 96.67 \\
\hline 11 & Canopy temperature $\left({ }^{0} \mathrm{C}\right)$ & III & GW2013-471 & 16.33 \\
\hline 12 & Days to maturity & V & $\begin{array}{l}\text { DBW14* } \\
\text { RAJ4120* }\end{array}$ & $\begin{array}{l}104.00 \\
110.00\end{array}$ \\
\hline 13 & Harvest index & III & GW2013-471* & 62.47 \\
\hline
\end{tabular}


Cluster II was suitable for early flowering. Therefore, these clusters may be chosen for transferring the traits having high mean values through hybridization programme. Selection of genotypes based on cluster mean for the better exploitation of genetic potential also reported by Dwivedi and Pawar (2004), Roy et al., (2009), Hailegiorgis et al., (2011) and Desheva and Kyosev (2014). The highest intra cluster distance (Table 4) was observed in cluster VI followed by cluster IV, cluster I, cluster $\mathrm{V}$ and cluster II indicating differences in genotypes within cluster. Least intra cluster distance was found in cluster II indicating that close resemblance between the genotypes presented in this cluster.

The genotypes in cluster III and cluster VI due to maximum inter cluster distance between them, exhibited high degree of genetic diversity and thus may be utilized under inter varietal hybridization programme (transgressive breeding) for getting high yielding recombinants. Similar inter varietal crosses may be attempted between genotypes in cluster V and VI and cluster II and IV. The lowest inter cluster distance was observed between cluster III and V followed by cluster I and III and cluster I and IV showing these clusters were relatively less divergent and crossing between them cannot produce vigorous offspring ( $\mathrm{F}_{1}$ progenies). These results of genetic diversity study were in agreement with the finding of Gupta et al., (2002), Ribadia et al., (2007) and Sanghera et al., (2014) suggested that genotypes of most diverse cluster may be used as parents in hybridization programmes to develop high yielding varieties.

In the present study, 33 diverse genotypes were grouped into various cluster and suitable diverse genotypes were selected based on their cluster mean superiority and per se performance for different characters. LBPY2014-7 grouped in cluster I exhibited superiority for grain yield per plot based on highest cluster mean and significant superior per se performance. This genotype also exhibited superiority for tillers per plant based on highest cluster mean and superior per se performance. GW2013-471 grouped in cluster III exhibited superiority for chlorophyll content and harvest index based on highest cluster mean and significant superior per se performance. GW2013-471 also exhibited superiority for relative water content based on highest cluster mean and superior per se performance. This genotype also exhibited superiority for canopy temperature based on lowest cluster mean and superior per se performance. RAJ4120 and DBW 14 grouped in cluster $\mathrm{V}$ exhibited earliness in days to maturity based on cluster mean (lowest) and significantly superior per se performance (Table 5). LBPY-2013-1 grouped in cluster I exhibited superiority for thousand grain weight based on highest cluster mean with superior per se performance. RAJ4120 and DBW14 of cluster V also exhibited superiority for plant height based on lowest cluster mean with superior per se performance. 4051, 4043, 3054,7004, HUW234 grouped in cluster II exhibited earliness in days to fifty per cent flowering based on cluster mean (lowest) and significantly superior per se performance. $21^{\text {st }}$ SAWYT307, $21^{\text {st }}$ SAWYT332, $34^{\text {th }}$ ESWYT146, 46 ${ }^{\text {th }}$ IBWSN1095, AKAW4900, $8^{\text {th }} \quad$ EBWYT507, LBPY-2014-7, $21^{\text {st }}$ SAWYT316, LBPY2013-1 grouped in cluster I exhibited superiority for spike length and grains per spike based on highest cluster mean with significantly superior per se performance. AKAW 4900 grouped in cluster I also exhibited superiority for flag leaf area based on highest cluster mean with superior per se performance.

\section{Acknowledgment}

Authors wish to acknowledge Department of 
Plant Breeding and Genetics, Rajendra Agricultural University (RAU) Pusa for providing materials and other support.

\section{References}

Aharizad, S., Sabzi, M., Abolghasem, S., Mohammadi, and Khodadadi, E. 2012. Multivariate analysis of genetic diversity in wheat (Triticum aestivum L.) recombinant inbred lines using agronomic traits. Annals of Biological Research. 3(5): 2118-2126.

Ali, Y., Atta, B.M., Akhter, J., Monneveux, P. and Lateef, Z. 2008. Genetic variability, association and diversity studies in wheat (Triticum aestivum L.)Germplasm. Pakistan Journal of Botany. 40(5): 2087-2097.

Bergale, B. and Yildirim, M. 2001. Heat and drought resistances criteria in spring bread wheat: drought resistance parameters. Scientific Research and Essays. 5(13):1742-1745.

Bhusan, B., Bharti, S., Ojha, A., Pandey, M., Gourav, S.S., Tyagi, B.S. and Singh, G. (2013). Genetic Variability, correlation coefficient and path analysis of some quantitative traits in bread wheat. Journal of Wheat Research. 5(1): 21-26.

Bousba, R., Baum, M., Djekoune, A., Labadidi, S., Djighly, A., Benbelkacem, K., Labhilili, M., Gaboun, F. and Ykhlef, N. (2012). Screening for drought tolerance using molecular markers and phenotypic diversity in durum wheat genotypes. World Applied Sciences Journal. 16(9): 1219-1226.

Degewione, A., Dejene, T. And Sharif, M. (2013). Genetic variability and traits association in bread wheat (Triticum aestivum L.) genotypes. International Research Journal of Agricultural Sciences 1(2): 19-29.

Dencic, S., Kastori, R., Kobiljski, B. And Duggan, B. (2000). Evaluation of grain yield and its components in wheat cultivars and land races under near optimal and drought conditions. Euphytica. 133 (1): 43-52.

Department of Agriculture and Corporation. (2014). Agricultural statistic at a glance (www. agricoop.nic.in).

Desheva, G., and Kyosev, B. 2014. Genetic diversity assessment of common winter wheat (Triticum aestivum L.). Emir. Journal of Food Agriculture. 27(3): 283-290.

Dwivedi, A.N. and Pawar, I.S. (2004). Evaluation of genetic diversity among bread wheat Germplasm line for yield and quality attributing traits. Haryana Agriculture University Journal of Research. 32: 77-80.

FAO. (2014). The state of food and agriculture in Asia and the Pacific, Bangkok Fao.org/world/regional/rap/)

Fellahi, Z., Hannachi, A., Guendouz, A. And Boutekrabt, A. (2013). Genetic variability, heritability and association studies in bread wheat (Triticum aestivum L.) genotypes. Electronic Journal of Plant Breeding. 4(2): 1161.

Ferdous, M., Nath, U.K. and Islam, A. (2011). Genetic divergence and genetic gain in bread wheat through selection practices. Journal of Bangladesh Agricultural University. 9(1): 1-4.

Gupta, R.S., Tiwari, D.K., Deal, S.S. and Singh, R.P. (2002). Genetic diversity of bread wheat (Triticum aestivum L.). New Botanist. 29: 1-7.

Hailegiorgis, D., Mesfin, M. and Genet, T. (2011). Genetic divergence analysis on some bread wheat genotypes grown in Ethiopia. Journal of Central European Agriculture. 12(2): 344-352.

Huhn. M. (2008). Comments on the Calculation of Mean Harvest Indices. Journal of Agronomy and Crop Science. 165(2-3):85-90. 
Islam, E., Allahgholipour, M., Zarei, L. And Kiani, M. (2012).Genetic analysis of field and physiological indicators of drought tolerance in bread wheat (Triticum aestivum L.) using diallel mating design. African Journal of Biotechnology. 10(61):13071-13081.

Khodadadi, M., Mohammad, F. and Miransari, M. (2011). Genetic diversity of wheat (Triticum aestivum L.) genotypes based on cluster and principal component analyses for breeding strategies. Australian Journal of Crop Sciences. 5(17-24).

Korkut, K. Z., Baser, I. and Bilgin, O. 2001. Genotypic and phenotypic variability, heritability and phenotypic correlation for yield and yield components in bread wheat varieties. Acta Agronomica Hungarica. 49(3): 237-242.

Kumar, B., Lal, G.M., Ruchi and Upadhyay, A. (2009). Genetic variability Diversity and Association of quantitative traits with grain yield in Bread wheat (Triticum aestivum L.). Asian Journal of Agricultural Sciences. 1(1): 4-6.

Kumar, N., Markar, S., and Kumar, V. (2014). Studies on heritability and genetic advance estimates in timely sown bread wheat (Triticum aestivum L.). Bioscience Discovery. 5(1):64-69.

Kumar, S., Dwivedi, V.K. and Tyagi, N.K. (2003). Genetic variability in some metric traits and its contribution to yield in wheat (Triticum aestivum L.). Progressive agricultural. 3(1/2): 152153.

Lush, J.L. 1949. Heritability of quantitative characters in farm animals. Proceedings of $8^{\text {th }}$ Congress of Genetics and Heriditas. 35: 356-375.

Mahalanobis, P.C. 1936. On the generalised distance in statistics. Proceedings of National Institute of Science. India. 2: 49-55.
Majumder, D.A.N., Shamsuddin, A.K.M., Kabir, M.A. and Hassan, L. (2008). Genetic variability correlated response and path analysis of yield and contributing traits at spring wheat, Journal of Bangladesh Agricultural University. 6(2) 227-234.

Mokhtarpour, H., Teh, B.S.C Saleh., G. Selamat., A.B Asadi. And M.A Kamkar. B. (2010). Non-destructive estimation of maize leaf area, fresh weight, and dryweight using leaf length and leaf width. Communications in Biometry and Crop Science. 5(1):19-26.

Raj Bahadur and Lodhi, G.P. (1995). Variability and association studies in wheat. Crop research. 9(2): 313-316.

Ranjana, K.H., Dobariya, K.I., Ponkia, H.P. and Jivani, L.L. (2013). Genetic divergence in macorni wheat (Triticum durum Desf.). Journal of Maharashtra Agriculture University. 32(1): 32-34.

Ribadia, K.H., Dobariya, K.I., Ponkia, H.P. and Jivani, L.L. (2007). Genetic divergence in macorni wheat (Triticum durum Desf.). Journal of Maharashtra Agriculture University.32 (1): 32-34.

Roy, B.K., Lal, G.M., Ruchi. And Upadhyay, A. (2009). Genetic variability, diversity and association of quantitative traits with grain yield in bread wheat (Triticum aestivum L.). Asian Journal of Agricultural Sciences. 1(1):4-6.

Sanghera, G.S., Kashyap, S.C., Rana, V. and Parry, G.A. (2014). Agromorphological and genetic diversity among elite wheat genotypes grown under Kashmir conditions. International Journal of Current Research. 6(8): 7735-7740.

Sen, C., and Tom, B., (2007). Character association and component analysis in wheat (Triticum aestivum L.). Agricultural Research Information Centre, Crop Research, Hisar India. 34 (1/3):166-170. 
Shoran, J. and Tandon, J.P. (1995). Genetic divergence of winter wheat (Triticum aestivum L.). Indian Journals of Genetics and Plant Breeding. 55 (4): 406-409.

Singh, A.K., Singh, S.K, Garg, H.S, Kumar, R. And Choudhary, R. (2014), Assessment of relationship and variability of morpho-phygiological characters in bread wheat (Triticum aestivum L.) under drought stress and irrigated conditions. The Bioscan. 9(2): 473-484.

Singh, M., Swarnkar, G.B., Lallu and Prasad, L. (2003). Genetic variability and path coefficient analysis in advances generation of bread wheat under rainfed condition. Plant Archives. 3(1): 89-92.

Singh, S.B., Singh, J.P. and Singh, T.B. (1997). Variability pattern in agromorphological characters in wheat (Triticum aestivum L.). Crop Research. 13(2): 391-396.
Singh, T., Sharma, A., and Alie, F.A., (2009). Morpho-physiological traits as selection criteria for yield improvement in mungbean (Vigna radiata (L.) Wilczek). Legume Research. 32 (1):3640.

Tsegaye, D., Dessalegn, T., Dessalegn, Y. and Share, G. 2012. Analysis of genetic diversity in some durum wheat (Triticum durum Desf) genotypes grown in Ethiopia. African J. Biotech. 11(40): 9606-9611.

Yadav, S.K., Singh, A.K. (2014). Assessment of genetic variability, and diversity for yield and its contributing traits among CIMMYT based wheat germplasm. Society for advancement of wheat research. 6(2): 154-159.

Yadav, S.N., Vadaya, S.N.P., and Kumar, P., (2006). Genetic divergence in wheat. Indian Journal of Genetics. 4:104-105.

\section{How to cite this article:}

Rajshree and Satish Kumar Singh. 2018. Assessment of Genetic Diversity in Promising Bread Wheat (Triticum aestivum L.) Genotypes. Int.J.Curr.Microbiol.App.Sci. 7(03): 676-684. doi: https://doi.org/10.20546/ijcmas.2018.703.079 